\title{
Another Look at the Impact of Nigeria's Growing Population on the Country's Development
}

\author{
Emmanuel C. Onwuka \\ Department of Economics, \\ Ambrose Alli University, \\ Ekpoma, Edo State. \\ Nigeria.
}

\begin{abstract}
This paper is a contribution to the debate about the impact of Nigeria's growing population on the country's development. With a population that already exceeds 130 million people and growing at roughly 3 per cent annually, a considerable proportion of the nation's resources are consumed instead of accumulated for development purposes. In effect, the paper empirically tests the association between population growth and economic development in Nigeria between 1980 and 2003 and found that growth in population outweighs that of output and this has hindered the capacity of successive governments to efficiently provide social services to the people, thereby negatively affecting development. Our contention, therefore, is that curbs on population growth through appropriate policies that would integrate the country's population programmers into the mainstream development efforts are necessary. That way, higher per capita consumption of social services by the citizens would be facilitated and which ultimately would boost their access to the benefits of development.
\end{abstract}

\section{Introduction}

Much of contemporary economics on population problems has centered on what could be the optimum size and its impact on economic growth and development (see, for example, Caldwell, 1990; National Research Council, 1993; Onokerhoraye, 1995; Bongaarts, 1996; Bloom and Williamson, 1998; United Nations, 1999; FAO 2000, UNDP, 2001 and Onwuka, 2003). This economics originated from the question posed by Malthus (1803) as to whether food production could keep pace with the demand of a growing population and his answer that the power of population is indefinitely greater than the resources on earth to provide the needed subsistence for mankind. The debate triggered by the Malthusian hypothesis points to a lack of universal applicability of his paradigm because in industrial countries, technological advances have spurred increases in agricultural production, which ensures food security for the citizens. For those countries, his predictions are somewhat negated, whereas a large number of developing countries remain trapped under conditions capable of validating them (Olofin, 1996; Smil, 2000). 
The efforts of governments in the developing countries to feed their peoples and also provide quality social services for them are being frustrated by rapid population growth. This growth is attributable, on the one hand, to improvement in human survival associated with the application of modern medical science to health matters, better sanitation and immunization of children, which have caused the death rate to decrease (Ashford, 2001; United Nations, 2001a). On the other hand, the traditional beliefs about the value of children, particularly sons, as an asset to be relied upon by their parents in agricultural production and to support them during old age have combined with the practice of polygamy, the fear of child mortality and low levels of female education to encourage high fertility. Moreover, the continuity of the patrilineal decent group and the influence of religions, which teach that children are gifts from God sharply limits the prospects for lowering the birth rate (for details, see Lee and Miller, 1990; Renne, 1995; Ainsworth et al., 1996 and National Population Commission, 2003).

Consequently, the world population has been increasing and the last two decades have been demographically unprecedented as it rose from 4.8 billion people in 1985 to 6.4 billion in 2004. Much of this increase occurred in the developing nations as their populations grew from 3.7 billion to 5.1 billion as against that of developed nations which grew from 1.1 billion to 1.2 billion over the same period (United Nations, 2001b; Population Reference Bureau, 2004). When it is noted that the high fertility countries are mainly resource constrained with low levels of social and economic development, it becomes obvious why they have accepted responsibility to control the growth of their populations through endorsement of family planning programmes mapped out at various international conferences organized by the United Nations (United Nations, 1998).

Nigeria is a high fertility country and there is evidence that its large population inhibits government's efforts in meeting the basic needs of the people. With a population that already exceeds 130 million people and growing at roughly 3 per cent annually, (United Nations, 2004), a considerable proportion of the country's resources is, doubtless, consumed instead of being accumulated as capital for development purposes. To that extent, the rate of development lags behind that of population growth, which triggers stagnation in social service delivery. This necessarily impedes whatever progress being achieved in the fight against poverty.

Our objective in this paper is to ascertain the validity of the assumed inverse association between population growth and economic development in Nigeria. Using regression techniques, we test this association for the period 1980-2003 and use the results to assess the impact of demographic change on government's social obligation to the people. 
The 23 years are chosen because they cover the oil boom, the economic crisis as well as the structural adjustment and post structural adjustment periods. In line with this setting, the contents of the paper are adumbrated as follows. Section I provides background information on demographic trends. Section II investigates the implications of population growth for development in Nigeria. In section III, we present the models including results of the regression analysis on the relationship between population growth and economic development in Nigeria while section IV summarizes the findings and offers conclusions.

\section{The Dynamics of Population Growth in Nigeria and its Implications for the Country's Development}

A large body of demographic literature documents the incidence of population growth in Nigeria (see, for example, Olusanya and Pursell, 1981; Farooq, 1985; Feyisetan and Ainsworth, 1996; Anyinwe and Okojie, 1998; National Population Commission, 2002 and Federal Republic of Nigeria, 2004a). Ordinarily, this growth in population would not be a cause for concern since in certain circumstances, a large population could be to the advantage of a country in terms of the sheer size of its domestic market, better division of labour, increased productivity through improvement in the ratio of labour force to population as well as enhancement of its political and military power. A large population also diversifies the demand for products and services and promotes the tendency to increasing returns to scale, thereby raising economic development (Yesufu, 2000).

Additionally, advances in the arts, sciences and technology are the purview of highly talented individuals and invariably the larger the population, the more likely would be the number of such individuals in the society (Jakande, 1988; Mauldin and Sinding, 1993 and Idele, 1997). Admittedly, population growth puts severe pressures on existing resources, but as Simon (1996) observes, such growth ushers in needed adjustments that neutralize the effects of depleting resources through the search for substitutes by stimulating technological change. Put differently, the ultimate resource is people who exert their dexterity to manage the challenges of development. When viewed from that perspective, population growth is not necessarily a problem but an opportunity in disguise.

Be that as it may, Nigeria's large population has development implications.To begin with, it does not augur well for planning purposes. Plans only succeed when the implementation is pursued with reliable data. But in the Nigerian experience, the unreliability of demographic data makes plan implementation a futile exercise in the country. (African Development Bank, 2001). 
Studies described elsewhere (World Bank, 1994; United Nations, 1998; Adonri, 2003) also detail other negative consequences associated with demographic change in Nigeria such as health complications arising from pregnancies that occur too early or too frequently during the reproductive life cycle. Population and health are thus closely related when considering high-risk pregnancies. By preventing such pregnancies, a significant impact can be made in enhancing the quality of life of the mother and child and by extension that of the entire population.

Rapid population growth in Nigeria is equally associated with unemployment with figures ranging from 17 per cent per annum for the entire population to 60 per cent for the youths because job opportunities are fewer than the number seeking for them, and stagnating economic performance because a larger proportion of available resources is consumed instead of invested to generate growth (Federal Republic of Nigeria, 2004b). In addition, it poses continuous pressure on resources, particularly on agricultural land. For instance, due to high density of people in the Eastern states as much as 53 per cent of the farming population cultivate less than 0.4 hectares in a given year and in the more congested areas of these states most farmers cultivate only 0.2 hectares per year. The result is fragmentation of farmlands and their subdivision into smaller plots to accommodate the growing farming populace. With time, the small plots would become untenable for even subsistence farming, forcing those concerned to move into marginal soils, where greater degradation takes place with attendant reduction in agricultural output (Akinbode, 2002; Madu, 2005).

The application of modern farming techniques and fertilizers could assuage this problem, but unfortunately as a capital deficient country, the traditional methods of farming dominate agricultural practice in Nigeria. Inevitably, therefore, population pressure on a fixed factor like land would usher in diminishing returns (Iniodu, 1998). This is one of the explanations to decreasing peasant income and accompanying widespread poverty among the rural dwellers, the incessant food shortages and insufficient calorie intake among the Nigerian people.

The changes in the structure of Nigeria's population continue to shift in favor of the young age group 0-14. This age group accounted for 43 per cent of the population during the 1963 census, but the figure increased to 45 per cent of the population during the 1991 census as Table 1 demonstrates. 
Table 1: Numerical and Percentage Distribution of the Population of Nigeria by Five Year Age Groups in the 1963 and 1991 Population Censuses

1963 Census

Age Group Total

(Years)

$0-4 \quad 9,549,163.00$

5-9 $\quad 8,439,298.00$

10-14 5,937,125.00

15-19 5,251,184.00

20-24 65,923,188.00

25-29 5,570,585.00

30-34 4,325,578.00

35-39 2,478,446.00

40-44 2,410,144.00

45-49 1,168,048.00

$50-54 \quad 1,216,899.00$

55-59

60-64

65-69

70-74

75-79

80-84

$85+$

Nigeria $55,670,055.00$
$463,476.00$

$785,792.00$

$272,899.00$

$314,323.00$

$125,838.00$

$191,156.00$

$246,893.00$

\section{Census}

Age Group
(Years)

Total

$\%$

17.2

15.2

10.7

0-4

$5-9$

10-14

15-19

20-24

25-29

30-34

35-39

40-44

45-49

50-54

55-59

60-64

65-69

70-74

75-79

80-84

$85+$

Nigeria

$\begin{array}{rr}143,438,889.00 & 16.1 \\ 14,500,458.00 & 16.3 \\ 11,148,681.00 & 12.5 \\ 9,335,788.00 & 10.5 \\ 7,671,570.00 & 8.6 \\ 7,311,671.00 & 8.2 \\ 5,913,927.00 & 6.6 \\ 4,214,933.00 & 4.7 \\ 3,845,918.00 & 4.3 \\ 2,416,703.00 & 2.7 \\ 2,570,799.00 & 2.9 \\ 1,119,769.00 & 1.3 \\ 1,690,374.00 & 1.9 \\ 763,940.00 & 0.9 \\ 886,302.00 & 1.0 \\ 351,823.00 & 0.4 \\ 480,686.00 & 0.5 \\ 424,989.00 & 0.5 \\ 88,992,220.00 & 100\end{array}$

Sources: Federal Office of Statistics (1989), Digest of Statistics, Lagos, Federal Office of Statistics, p.5; National Population Commission (1998), 1991 Population Census of the Federal Republic of Nigeria: Analytical Report at the National Level, Abuja, National Population Commission, p.40.

Granted that the elderly population of 65 years and above is substantially smaller than the young population as Table 1 also bears witness, the percentage of the elderly population is expected to increase with better medical services. This implies a high proportion of people at the non-productive tender age and the aged, which together constitute about 48 per cent of the population. The high percentage of youth and aged in the population easily render social welfare programs of government and international agencies mere tokenism gesture (National Population Commission, 2004b). The heavy outlays on child welfare and social security and even heavier tax burden on the labor force to support the young and elderly are clear manifestations of contradictions inherent in the management of a large population in the face of inadequate resources. 
The situation has been compounded by the economic crisis in the country. The causes and effects of this crisis have been extensively discussed in the literature (see, for example, Soleye, 1987; Essien, 1990; Obadan and Ekuerhare, 1993; Onimode, 1995, Onwuka, 1996; Umoren, 2001; Ajakaiye, 2003). Suffice, however, to observe that the crisis has brought about declines in social expenditures, whereas the population has maintained a steady rise. A typical example is the education sector. The introduction of Universal Primary Education Scheme in 1976 and its modification into the Universal Basic Education Program in 1999 has meant increases in primary school enrolments from 9.9 million to 27 million, while that of secondary schools from 998,976 to 7.5 million between 1977 and 2002 (Central Bank of Nigeria 1980 and 2003a). The demand for tertiary education has equally been high as enrolments increased from 135,783 during 1985/86 session to 350,000 during 1999/2000 session in the universities (Olaniyan, 2001; Adalemo, 2001). As such, there have been more intakes into educational institutions with the expectation of corresponding higher spending on the educational sector.

But the share of public expenditures on education has plummeted over the years. It fell from 7.8 per cent of total federal government expenditures in 1994 to 4.5 per cent in 2003 (Hinchliffe, 2002; Federal Office of Statistics, 2003).

Because of the slashes in educational expenditures, investments have not kept pace with the demands of that sector. In effect, infrastructures have been overstretched; causing their dilapidation and inadequate teaching materials and understaffing engender deterioration in learning outcomes. Many eligible candidates are also denied admission into Nigerian universities due to inadequate facilities. For example, in 1990, 373,016 candidates applied for admission, but only 61,212 representing 16.4 per cent were admitted. In 2000, 467,490 applied for admission, but only 50,277 representing 10.8 per cent could be absorbed even though that human capital formation is critical for the country's development (JAMB Annual Reports 1991 and 2001).

The health sector suffers the same investment fatigue, with aggregate growth rates of 2 per cent and 1.2 per cent for the capital and recurrent expenditures respectively for the period between 1985 and 2002, being lower than the population growth rate of 3 per cent (Central Bank of Nigeria, 2003b). Little wonder that public health institutions are overburdened by operational costs per capita. Overuse negatively impacts on the physical conditions of their facilities and the growing number of patients reduces the availability of drugs in hospitals, overwhelms the laboratories and machines employed in medical practice with attendant inefficiency in health care delivery. 
Other social services like safe drinking water, good housing and constant electricity supply have become luxuries in Nigeria because as efforts are made to satisfy some communities, teeming numbers elsewhere yearn for attention, thereby dwarfing whatever achievements made in the realm of human development. For instance, the proportion of the Nigerian population with access to safe drinking water and adequate sanitation in 1999 was 54.1 percent and 52.8 percent respectively (Federal Office of Statistic /UNICEF, 2000). The housing situation has worsened and the number of homeless people has increased, while urban slums have risen in size (UNSN, 2002).

These submissions do not imply that once population is growing, social services must crumble. On the contrary, robust economic growth coupled with equitable distribution of income lesson the negative consequences of population growth on development as the experiences of China, Indonesia and South Korea demonstrate. In Nigeria, however, growth has been sluggish and the gap between the rich and the poor keeps widening to the extent that the share of the poorest 20 per cent of the population in national consumption amounted to only 4 per cent in 2002, while that of the richest 20 per cent was 56 per cent (Federal Republic of Nigeria, 2004c). A study by UNECA (1999) confirms this high income inequality among Nigerian citizens with a Gini coefficient of 44.4 per cent in the 1990s.

Corruption and bad governance erode the confidence of the people in their government. This reduces their enthusiasm in the struggle for socioeconomic revival and stability. Although there appears to be no link between population growth and low savings in Nigeria, the fact remains that as population grows, "capital widening" is needed to maintain existing per capita income and savings while declining fertility makes it possible for resources to be released for "capital deepening", which helps the cause of poverty alleviation.

The forgoing arguments strengthen our belief that Nigeria has a population load factor that weights too heavily on its meager resources to guarantee the welfare of the citizens. Since the basic needs of the people are not adequately catered for, exacerbation of poverty is inevitable as rural decay and urbanization crunch intensify. That is why curbs are needed in Nigerian population growth rate to a level that is supportive of efforts to achieving sustainable development in the country.

\section{Model Formulation and Data Analysis}

This section deals with the empirical evaluation of the effects of Nigeria's growing population on economic development. The model adopted, with some modifications, is that of Blanchet (1999) on the effect of population 
growth on economic development. In that model, Blanchet distinguishes between the supply and demand effects of population growth on economic development in order to obviate the criticism associated with positive or negative results obtained when population growth is estimated unblock.

\section{The Supply Effect of Population Growth on Economic Development}

Blancher's model specifies that total output $(\mathrm{Y})$ is a function of economically active population or the labor force (L). This is expressed algebraically as follows

$\mathrm{Y}=\mathrm{L}(\mathrm{t}) \exp \mathrm{B}(\mathrm{t})$

where

$\mathrm{Y} \quad=$ total output

$\mathrm{L}(\mathrm{t}) \quad=$ economically active population per time period

$\operatorname{Exp} B(t)=$ exogenous rate of technical progress

The relationship in equation 1 can be rewritten in terms of per capita income as follows

$\mathrm{dy} / \mathrm{y}=\mathrm{a}+\beta \mathrm{dL} / \mathrm{L}$

Equation 2 gives the supply effect of population growth, i.e. more people, more products. A positive relationship is, therefore, expected for the regression of per capita income $(\mathrm{dy} / \mathrm{y})$ on growth rate of labour output $(\mathrm{dL} / \mathrm{L})$.

\section{The Demand Effect of Population Growth on Economic Development}

If we incorporate into equation 2 the growth rate of population $(\mathrm{dp} / \mathrm{p})$, where $\mathrm{p}$ is the total population, we have

$$
\mathrm{dy} / \mathrm{y}=\mathrm{a}+\beta \mathrm{dL} / \mathrm{L}-\mathrm{dp} / \mathrm{p}
$$

There are two basic assumptions about equation 3. The first assumption is that there is decreasing return to scale, which follows from the fact that there is a fixed or slightly variable production factor (for instance, land in an agricultural economy). The expectation is that a larger population would imply increased production, but at a rate less than that of population growth, hence a decline in per capita income. The second assumption is that the economically active population and the total population grow at the same rate. This implies from equation 3 that

$$
\begin{aligned}
& \mathrm{dy} / \mathrm{y}=a+\beta d p / p-d p / p \\
& \mathrm{dy} / y=a+(\beta-1) d p / p
\end{aligned}
$$


The coefficient $\beta$ being positive, the slop of the regression should in principle be greater than 1 . If it is greater than 0 , it is because returns to scale are increasing, i.e. $\beta>1$. Therefore, the expectation of a negative correlation in the regression is justified if the demand effect is stronger than the supply effect.

Our modification to the Blanchet model is introduced here with the inclusion of oil production and lagged per capita output in Nigeria to reflect an implicit adjustment mechanism and adjustment response. In this way, we have a multiple regression equation of the type

$$
\mathrm{dy} / \mathrm{y}=\alpha+(\beta-1) \mathrm{dp} / \mathrm{p}+\frac{\beta_{1} \operatorname{Er}+\beta_{2}}{\operatorname{Er}} \frac{\mathrm{dyt}-1}{\mathrm{yt}-1}
$$

where

$\mathrm{Er} \quad=$ oil production

dyt -1 = lagged per capita output

$\beta_{1}$ and $\beta_{2}=$ are expected to be positive

Based on this modification, our regression equation becomes

$$
\begin{aligned}
& \frac{d y R}{y R}=a+a_{1} d p R / p R+u_{1} \\
& \text { dy } \quad=a+a_{2} d p / p+u_{2} \\
& \overline{\mathrm{y}} \\
& \frac{d y}{y}=a+a_{3} d y t-1+u_{3} \\
& \frac{d y}{y}=a+a_{4} \frac{d E r}{E r}+u_{4} \\
& \underline{d y} \quad=a+a_{5} \underline{d \beta p}+u_{5} \\
& 10 \\
& \text { y } \quad \beta p \\
& \underline{d y}=a-a_{6} \underline{d p}+a_{7} \underline{d y t-1}+a_{8} d E r \quad+u_{6} \\
& \text { y } \quad p \quad y t-1 \quad \text { Er } \\
& \underline{d y}=a-a_{9} \underline{d p}+a_{10} \underline{d y t-1}+a_{11} d E r+a_{12} \underline{d \beta p}+u_{7} \\
& \frac{d y}{12} \\
& \mathrm{y} \\
& \text { p yt }-1 \\
& \text { Er } \quad \beta p
\end{aligned}
$$




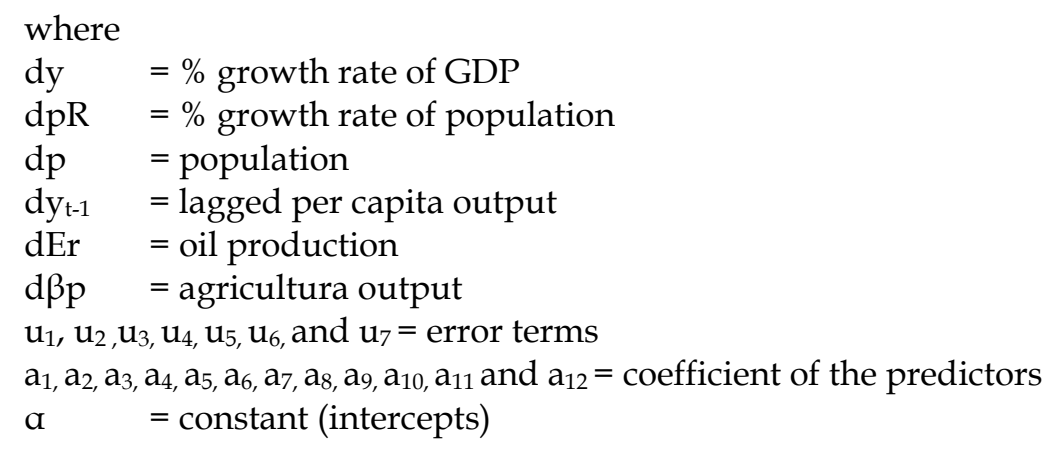

The per capita agricultural output is introduced into the equation because apart from being used conventionally in population studies as a dependent variable, Nigeria is an economy with low agricultural output. Equation 8 is the per capita output incorporating only the supply effect of population growth. Since data on $\mathrm{dL} / \mathrm{L}$ are not available on a yearly basis in Nigeria, we could not model equation 3. However, the value of $\beta-1$ could be generated if we equate $\beta$ to the slope of $d p / p$ in the regression analysis, i.e. $(\beta-1)=a_{2}$. This will enable us to examine the nature of $\beta$ which Blanchet did not analyze

An ordinary least squares technique is used to estimate equations 6 to 12. The problems of multicollinearity were considered when deciding the combinations of the predictors for the various models. The data used for the regression runs are shown in Appendix I. The results of the regression estimates for equations 6 to 12 are presented in Appendix II. In all cases, $R^{2}$ and $R^{2}$ (adjusted) measure the explanatory power of the multiple regressions while $\mathrm{F}$ statistics test the significance of the regression coefficients of determination. The $t$ - statistics are reported in the parenthesis under relevant coefficients.

The results of the estimates from 1980-2003 support our a priori expectation about population growth and economic development in Nigeria. However, between 1982 and 1997 the negative relationship between these two phenomena did not manifest apparently due to growth in production and lagged per capita output, although agricultural production showed a negative sign because of low productivity in that sector. Estimates from equation 12 indicate that the regression is fairly good fit $\left(R^{2}=70 \%\right)$. The positive sign and the coefficient of oil export are explained by increases in oil price for most of the years.

From the analysis, the demand effect is understandably greater than the supply effect because population grows faster than output in Nigeria. The disparities in production and consumption so engendered are detrimental to economic growth as capital accumulation is hindered in the process. That is why curbs on population growth are necessary for efficient delivery of social services such that development efforts would have a positive impact on the lives of the people. 


\section{Summary and Concluding Remarks}

The arguments advanced in this paper can now be summarized with concluding remarks. Population size is relevant to the development aspirations of Nigeria since people are both producers and consumers of socio-economic products and their number is an indicator that approximates the country's need for basic services. The empirical investigation validates our expectation that rapid population growth is inimical to the development of Nigeria. Although the introduction of variables like oil production and lagged per capita output mitigate the effect of population growth on economic development in the country, this erroneous impression should be discountenanced because Nigeria cannot sustain a much larger population given the country's circumstances.

Although human rights have improved since the enthronement of democracy in 1999, poverty has persisted in Nigeria. Freedom from illiteracy and illness which are vital routes of escape from poverty eludes Nigerians because as the population grows, the corrupt elite that maintain a stranglehold on political power would not invest adequately in the appropriate sectors.

As a poor economy, rapid population growth inevitably reduces agricultural output per capita, leading to food insecurity and high fertility causes overall income per head to decline. Basic services fail Nigeria people in access, quality and quantity in part due to large population. Common sense dictates that when population grows exponentially, the provision of basic services must also expand; requiring increased public interventions per capita in the appropriate sectors. The niggardliness in investing on education, health and other basic needs coupled with inefficient economic management, add important dimensions to the poverty orchestrated by ineffective delivery of social services.

Nigeria, therefore, has a daunting task in addressing the challenges posed by its large population. This calls for response measures through appropriate programs that would integrate the country's population policies into the mainstream development efforts. That way, higher per capita consumption of basic services by the people would be facilitated for them to enjoy the fruits of development. 


\section{References}

Adalemo, I. A. (2001), Higher Education in Nigeria: Institutional Inadequacies, System Performance and Sustainability, in Paths to the Sustainability of Higher Education in Nigeria, Proceedings of the 12 th General Assembly of the Social Science Academy of Nigeria, Abuja, Social Sciences Academy of Nigeria.

Adonri, O. (2003), Integration of Population Data in Socio-economic Planning, in Nigeria Population Census 1991 Analysis: Relevance of Census Data to Public and Business Administration, Abuja, National Population Commission.

African Development Bank (2001), African Development Report (2001), Fostering Good Governance in Africa, Oxford, Oxford University Press.

Ainsworth, M.; Beegle, K. and Nyamete, A. (1996), The Impact of Women's Schooling on Fertility and Contraceptive Use: A Study of Fourteen SubSaharan African Countries, in The World Bank Economic Review 10 (1): 85122.

Ajakaiye, D. O. (2003), Economic Development in Nigeria: A Review of Experience, in Garba, A. (ed): Development Thought, Policy Advice and Economic Development in Africa in the 20th Century: Lessons for the 21 ${ }^{\text {st }}$ Century, Ibadan, Ibadan University Press.

Akinbode, A. (2002), Introductory Environmental Resource Management, Ibadan, Daybis Limited.

Anyinwe, M.A. and Okojie, C.E.E. (1998), Economic Implications of the Unmet Need for Family Planning Services, in The Nigerian Journal of Economic and Management Studies 3 (1 \& 2): 46-56.

Ashford, L.S. (2001), New Population Policies: Advancing Women's Health and Rights, in Population Bulletin 56 (1): Washington, Population Reference Bureau.

Blanchet, D. (1999), Reversal of the Effects of Population Growth on Economic Growth Since the End of the 1970s: Reality or Artefact?, in Population Growth and Demographic Structure, Proceedings of the United Nations Expert Group Meeting on Population Growth and Demographic Structure, New York, United Nations.

Bloom, D.E. and Williamson, J.G. (1998), Demographic Transition and Economic Miracle in Emerging Asia, in The World Bank Economic Review 12(3): 45-53.

Bongaarts, J. (1996), Population Pressure and Food Supply System in the Developing World, Research Division Working Papers No. 86, New York, The Population Council.

Caldwell, J.C. (1990), The Soft Underbelly of Development: Demographic Transition in Conditions of Limited Economic Change, in Fisher, S. et. al. (ed): Proceedings of the 1990 World Bank Annual Conference on Development Economics, Washington, The World Bank.

Central Bank of Nigeria (1980), Annual Report and Statement of Accounts for the Year Ended 31st December 1979, Lagos, Central bank of Nigeria

Central Bank of Nigeria (2003a), Annual Report and Statement of Accounts for the Year Ended 31 ${ }^{\text {st }}$ December, 2002, Abuja, Central Bank of Nigeria.

(2003b), Central Bank of Nigeria Statistical Bulletin, Vol. 14, Abuja, Central Bank of Nigeria.

Essien, E. (1990), Nigeria Under Structural Adjustment, Ibadan, Fountain Publications. 
FAO (2000), Population and the Environment: A Review of Issues and Concepts for Population Programmes, Part III, Population and Deforestation, Rome, Food and Agriculture Organization of the United Nations.

Farooq, G. (1985), Household Fertility Decision-Making in Nigeria, in Farooq, G.F. et. al. (ed): Fertility in Developing Countries, London, Macmillan Press.

Federal Office of Statistic/UNICEF (2000), Multiple Indicators Cluster Survey, Abuja, Federal Office of Statistics.

Federal Office of Statistics (2003), Annual Abstract of Statistics 2003, Abuja, Federal Office of Statistics.

Federal Republic of Nigeria (2004a), National Policy on Population for Sustainable Development, Abuja, Federal Government Press.

(2004b), Background Paper on Employment and Poverty Alleviation in Nigeria Presented to the African Union Extraordinary Summit on Employment and Poverty Alleviation in African, Ouagadougou, $8^{\text {th }}-9^{\text {th }}$ September, 2004, Abuja, Federal Government Press.

(2004c), Millennium Development Goals Report 2004: Nigeria, Abuja, Federal Government Press.

Feyisetan, B.J. and Ainsworth, M. (1996), Contraceptive Use and the Quality, Price and Availability of Family Planning in Nigeria, in The World Bank Economic Review 10 (1): 159-187.

Hinchliffe, K. (2002), Public Expenditures on Education in Nigeria: issues, Estimates and Some Implications, Africa Region Human Development Working Papers Series, Washington, The World Bank.

Idele, S.I. (1997), On the Economics and Politics of Large Population: Nigeria in the New Policy Debate, in The Nigerian Economic and Financial Review 2 (2): 3645.

Iniodu, P.U. (1998), The Impact of Agricultural Practices on Food Security in Eastern Nigeria, in The Nigerian Journal of Economic and Management Studies 3 (1 \& 2): 91-103.

Jakande, L.K. (1988), Nigeria's Population Question: A New Approach, in Oyekanmi, F.D. et. al (ed): Viable National Population Census: The Road to 1991, Proceeding No.7, Selected Papers of the Seventh Annual Conference of the Population Association of Nigeria, Lagos, Population Association of Nigeria.

JAMB (1991), Annual Report of The Joint Admissions and Matriculation Board into Nigerian Universities for 1990, Abuja, Joint Admissions and Matriculation Board.

(2001), Annual Report of The Joint Admissions and Matriculation Board into Nigerian Universities for 2000, Abuja, Joint Admissions and Matriculation Board.

Lee, R.D. and Miller, T. (1990), Population Growth, Externalities to Childbearing and Fertility Policy in Developing Countries, in Fisher, S. et al (ed): Proceedings of the 1990 World Bank Annual Conference on Development Economics, Washington, The World Bank.

Madu, I.A. (2005), Population and Settlement Constraints to Sustainable Agricultural Land-Use in South Eastern Nigeria, in Okoko, E. et. al. (ed): Environmental Sustainability and Conservation in Nigeria: A Book of Readings. Akure, Jubee - Niyi Publishers.

Malthus, T.R. (1803), Essays on the Principles of Population, London, Bensley Publishers. 
Mauldin, W.P. and Sinding, S.W. (1993), Review of Existing Family Planning Policies and Programmes: Lessons Learned, New York, The Population Council.

National Population Commission (2002), Sentinel Survey of the National Population Programme: Baseline Report 2000, Abuja, National Population Commission. (2003), Nigeria Demographic and Health Survey 2003, Calverton, National Population Commission and ORC/Macro.

National Research Council (1993), Population Dynamics of Sub-Saharan Africa: Demographic Effects of Economic Reversals in Sub-Saharan Africa, Washington, National Academy Press.

Obadan, M.I. and Ekuerhare, B.U. (1993), The Theoretical Basis of Structural Adjustment Programmes: An Appraisal, in The Nigerian Journal of Economic and Social Studies 25 (1): 17-32.

Olaniyan, O. (2001), Public Finance and Higher Education in Nigeria, in Paths to the Sustainability of Higher Education in Nigeria, Proceedings of the $12^{\text {th }}$ General Assembly of the Social Science Academy of Nigeria, Abuja, Social Science Academy of Nigeria.

Olofin, S. (1996), Are We Destined for Economic Backwardness in Perpetuity? A NeoMalthusian Theory of Underdevelopment, Ibadan, University of Ibadan Press.

Olusanya, P.O. and Pursell, D.E. (1981), The Prospects of Economic Development in Nigeria Under Conditions of Rapid Population Growth, Ibadan, The Nigerian Institute of Social and Economic Research.

Onimode, B. (1995), Economic Development Policy in an Open Economy: The Nigerian Experience Since 1960, in Iwayemi, A. (ed): Macroeconomic Policy Issues in an Open Developing Economy: A Case Study of Nigeria, Ibadan, National Center for Economic Management and Administration.

Onokerhoraye, A.G. (1995), Population Growth and the Provision of Social Services in Nigeria, The Benin Social Science Series for Africa, Benin-City, University of Benin.

Onwuka, E.C. (1996), Perspectives on the Deregulation of Nigeria's Agriculture, in Onwuka, E.C. et. al (ed): Economic Development in a Deregulated Economy, Ibadan, Stirling-Horden Publishers.

Onwuka E.C. (2003), Linkages Between Population Growth, Poverty and Environmental Degradation in Nigeria, in Adekunle, V.et.al. (ed): Challenges of Environmental Sustainability in a Democratic Government, Proceedings of a National Conference Organized by the Environment and Behaviour Association of Nigeria, Akure, EBAN.

Population Reference Bureau (2004), 2004 World Population Data Sheet of the Population Reference Bureau, Washington, Population Reference Bureau.

Renne, E.A. (1995), Houses, Fertility and the Nigerian Land Use Act, in Population and Development Review 21 (1): 75-90.

Simon, J. (1996), The Ultimate Resource 2, Princeton, Princeton University Press.

Smil, V. (2000), Feeding the World: A Challenge for the Twenty-First Century, Cambridge, MIT Press.

Soleye, O.O. (1987), Nigeria's Industrial Policy: Retrospect and Prospect, in Iyanda, O. (ed): The Nigerian Economy: Issues and Problems of Management, Lagos, Malthouse Press.

United Nations (1998), World Population Prospects. The 1998 Revision. Vol. III: Analytical Report, New York, United Nations.

(1999), Population Growth, Structure and Distribution: The Concise Report, New York, United Nations. 
(2001a), Population, Environment and Development: The Concise Report, New York, United Nations.

(2001b), World Population Prospects: The 2000 Revision, Vol. 1. Comprehensive Tables, New York, United Nations.

(2004), World Population Policies 2003, New York, United Nations.

UNECA (1999), Economic Report on Africa: The Challenge of Poverty Reduction and Sustainability, Addis-Ababa, United Nations Economic Commission for Africa.

UNDP (2001), Human Development Report: Nigeria 2000/2001, Lagos, United Nations Development Programme.

UNSN (2002), United Nations Development Assistance Framework: Nigeria 2002 - 2007, Abuja, United Nations System in Nigeria.

Umoren, R. (2001), Economic Reforms and Nigeria's Political Crisis, Ibadan, Spectrum Books.

World Bank (1994), Population and Development: Implications for The World Bank, Washington, The World Bank.

Yesufu, T.M. (2000), The Human Factor in National Development: Nigeria, Ibadan, Spectrum Books. 
APPENDIX 1 : Some Socio-Economic Indicators of Nigeria (1980-2003)

\begin{tabular}{|c|c|c|c|c|c|c|c|}
\hline Year & $\begin{array}{l}\text { GDP } \\
(\mathrm{Nm})\end{array}$ & $\begin{array}{l}\text { Population in } \\
\text { millions }\end{array}$ & $\begin{array}{l}\text { Lagged Per Capita } \\
\text { Income ( } \mathbf{N m})\end{array}$ & Oil Export ( $\mathrm{Nm})$ & $\begin{array}{c}\text { Agricultural Output } \\
(\mathrm{Nm})\end{array}$ & $\begin{array}{c}\text { Growth in GDP } \\
(\%)\end{array}$ & $\begin{array}{c}\text { Growth in Population } \\
(\%)\end{array}$ \\
\hline 1980 & 96.2 & 84.7 & - & 13523.0 & 106.4 & 5.4 & 2.5 \\
\hline 1981 & 70.4 & 86.7 & 710.0 & 10680.5 & 102.6 & -26.8 & 2.5 \\
\hline 1982 & 70.2 & 89.2 & 760.0 & 8003.2 & 114.2 & -0.28 & 2.8 \\
\hline 1983 & 66.2 & 95.4 & 550.0 & 7201.2 & 100.8 & 5.4 & 3.4 \\
\hline 1984 & 63.0 & 98.6 & 450.0 & 8840.6 & 102.4 & -5.3 & 3.2 \\
\hline 1985 & 68.9 & 101.1 & 530.0 & 10890.6 & 104.6 & 7.4 & 3.2 \\
\hline 1986 & 71.0 & 105.1 & 520.0 & 8368.4 & 108.3 & 3.00 & 3.0 \\
\hline 1987 & 70.9 & 108.6 & 540.0 & 28208.6 & 116.1 & -0.4 & -23.6 \\
\hline 1988 & 77.8 & 83.2 & 540.0 & 28435.4 & 138.5 & 10.0 & 2.0 \\
\hline 1989 & 83.5 & 84.9 & 540.0 & 35016.8 & 153.0 & 7.3 & 2.4 \\
\hline 1990 & 90.3 & 86.9 & 520.0 & 106626.5 & 167.5 & 8.1 & 2.3 \\
\hline 1991 & 94.6 & 88.9 & 580.0 & 116856.5 & 191.7 & 4.8 & 2.9 \\
\hline 1992 & 97.4 & 91.5 & 860.0 & 201383.9 & 206.4 & 2.9 & 2.8 \\
\hline 1993 & 100.0 & 94.1 & 990.0 & 213778.8 & 211.4 & 2.9 & 2.8 \\
\hline 1994 & 101.3 & 96.7 & 102.6 & 200710.2 & 209.7 & 1.3 & 2.3 \\
\hline 1995 & 103.5 & 99.5 & 1050.0 & 728265.3 & 216.8 & 2.2 & 2.9 \\
\hline 1996 & 107.0 & 102.3 & 1026.0 & 729421.4 & 224.8 & 3.7 & 2.8 \\
\hline 1997 & 110.0 & 105.2 & 1052.0 & 166902.5 & 231.1 & 3.7 & 2.8 \\
\hline 1998 & 112.0 & 108.1 & 1048.4 & 175854.2 & 242.4 & 5.6 & 2.8 \\
\hline 1999 & 116.0 & 111.2 & 1041.9 & 1169476.9 & 249.1 & 2.7 & 2.8 \\
\hline 2000 & 120.0 & 114.3 & 1038.9 & 1929900.4 & 252.0 & 5.4 & 2.8 \\
\hline 2001 & 344.0 & 117.5 & 1046.8 & 1973222.2 & 260.1 & 4.6 & 2.8 \\
\hline 2002 & 356.0 & 120.8 & 1062.5 & 1787622.1 & 272.4 & 3.5 & 2.8 \\
\hline 2003 & 392.8 & 124.2 & 1065.4 & 27894754.2 & 294.6 & 10.3 & 2.8 \\
\hline
\end{tabular}

Sources: Computed by the Author from Central Bank of Nigeria Annual Reports and Statement of

Accounts (Various Years); Central Bank of Nigeria Statistical Bulletin (Various Years);

Nigerian National Petroleum Corporation's Inspectorate Division's Database (Various

Issues) and World Bank's World Development Indicators (Various Years). 
Appendix II : The Results of the Regression Estimates for Equations 6 to 12

\begin{tabular}{|c|c|c|c|c|c|c|c|c|}
\hline \multicolumn{9}{|c|}{ Model I $\frac{d y R}{y R}=\alpha-a_{1} \frac{d p R}{p R}$} \\
\hline Year & $\begin{array}{l}\text { Dependent Variable } \\
\text { Growth Rate of GDP }\end{array}$ & Intercept & $\begin{array}{l}\text { Coefficient of Explanatory } \\
\text { Variable }\end{array}$ & $R^{2}$ & $\bar{R}^{-2}$ & $\mathrm{~F}$ & DW & $\begin{array}{l}\text { Significa } \\
\text { nce } 5 \%\end{array}$ \\
\hline $\begin{array}{l}1980- \\
2003 \\
\end{array}$ & & $\begin{array}{l}3.276 \\
(2.140) \\
\end{array}$ & $\begin{array}{l}-0.281 \\
(-1.018) \\
\end{array}$ & 0.45 & 0.02 & 1.02 & 1.956 & NS \\
\hline \multicolumn{9}{|c|}{ Model II $\frac{d y}{y}=\alpha-a_{2} \frac{d p}{p}$} \\
\hline $\begin{array}{l}1980- \\
2003\end{array}$ & & $\begin{array}{l}-437.923 \\
(-3.722)\end{array}$ & $\begin{array}{l}5.626 \\
(4.431) \\
\end{array}$ & $\begin{array}{l}0.51 \\
7\end{array}$ & $\begin{array}{l}0.49 \\
1\end{array}$ & 23.2 & 0.712 & NS \\
\hline \multicolumn{9}{|c|}{ Model III $\frac{d y}{y}=\alpha-a_{3} \frac{d y_{t-1}}{y_{t-1}}$} \\
\hline $\begin{array}{l}1980- \\
2003\end{array}$ & & $\begin{array}{l}3.26 \\
(2.065)\end{array}$ & $\begin{array}{l}0.157 \\
(2.579)\end{array}$ & $\begin{array}{l}0.27 \\
2\end{array}$ & $\begin{array}{l}0.19 \\
7\end{array}$ & $\begin{array}{l}6.65 \\
4\end{array}$ & 0.45 & NS \\
\hline \multicolumn{9}{|c|}{ Model IV $\frac{d y}{y}=\alpha+\frac{E d r}{E r}$} \\
\hline $\begin{array}{l}1980- \\
2003\end{array}$ & & $\begin{array}{l}106.790 \\
(7.44)\end{array}$ & $\begin{array}{l}1.126 \\
(4.266)\end{array}$ & $\begin{array}{l}0.45 \\
3 \\
\end{array}$ & $\begin{array}{l}0.42 \\
8 \\
\end{array}$ & $\begin{array}{l}18.1 \\
95 \\
\end{array}$ & 1.044 & $S$ \\
\hline
\end{tabular}




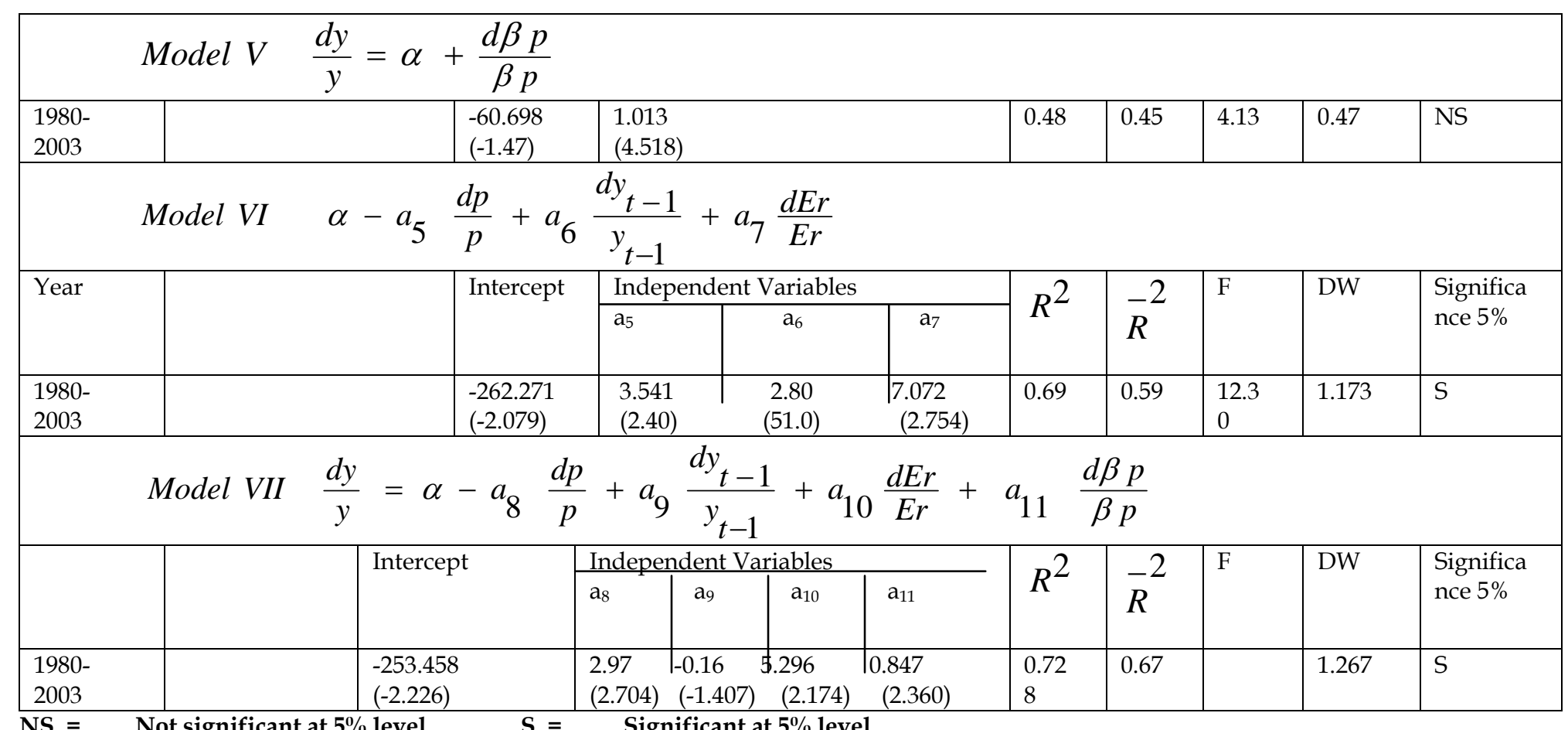

Source: Computed by the Author from Computer Printou 